\title{
The Russian Tourist Industry: Structure, Trends, Competitiveness at the World Market
}

\author{
Anton O. Ovcharov ${ }^{1}$, Marina V. Vasiljeva ${ }^{2} \&$ Sergey S. Shirin ${ }^{3}$ \\ ${ }^{1}$ Lobachevsky State University of Nizhni Novgorod, Nizhni Novgorod, Russian Federation \\ ${ }^{2}$ Publishing House "Scientific review" Moscow, Russian Federation \\ ${ }^{3}$ St. Petersburg State University, St. Petersburg, Russian Federation \\ Correspondence: Anton O. Ovcharov, Prospekt Gagarina, 23, Nizhni Novgorod, 603950, Russia. Tel: \\ 7-831-430-3843. E-mail: anton19742006@yandex.ru
}

Received: March 11, 2015 Accepted: March 30, 2015 Online Published: May 22, 2015

doi:10.5539/res.v7n9p151 URL: http://dx.doi.org/10.5539/res.v7n9p151

\begin{abstract}
The paper deals with the problems of Russian tourism with the use of statistic analysis methods. The structure of tourist economic sector is represented based on the international recommendations. The usage of adjusting factors having regard to the share of tourism within the activity of enterprises of various branches is suggested. Tourism development trends in Russia and in the world in general are revealed. Regional inequality of international incomes and expenses is demonstrated. The reasons of the Russian tourism low competitiveness on the world market are defined.
\end{abstract}

Keywords: statistics, tourist industry, types of economic activity, competitiveness, tourism expenditures, Russian tourism

\section{Introduction}

Among the benefits of strategic management are, for example, a clearer sense of strategic vision, sharper focus on what is strategically important and an improved understanding of a rapidly changing environment. A strategy consists of purposes, policies, programmes, actions, decisions, and/or resource allocations that define what an organisation is, what it does, and why it does it. Strategic decisions deal with the "big" things, covering multi-functional service areas and the long-term focused on innovation and core functions, and take into consideration the need for cultural change in order to create a business friendly environment. Strategy is essentially an emergent phenomenon, involving the crafting of a corporate culture through reviews of the organisation's present state, and formation of a mission and vision to guide its future development. The tourist industry is usually seasonal and strategies must therefore help regions to focus on their resources and increase local income from tourism throughout the year.

Tourist services consist of different elements, such as transportation, accommodation and activities at the place of destination. One of the major challenges is to integrate these services, resources, core competences and capabilities, so that the customer is rewarded with an unforgettable travel experience (Chen, Y. G., Chen, Ho, \& Lee, 2009). The tourist sector is labour intensive and often provides work for young adults. The problem is that this sector suffers from the seasonality of tourism, and seasonality has usually limited the economic contribution that tourism can make to the local economy.

Sharma and Dyer (Sharma \& Dyer, 2009) have listed several positive effects of tourism. Tourism increases, for example, employment, investments and tax revenues and demands the maintenance of high standards for roads and public facilities. It also encourages the development of a variety of cultural activities by local residents aimed at creating a positive impact on the cultural identity of the community.

As in any industrial sector, so in the tourism industry, the economic, social and technological factors, for example, affect the operational environment.

The tourist trade must have a multifarious infrastructure, including accommodation, restaurants, attractions, tours and transport connections. In many cases these are primarily developed by the private sector. Without basic services (e.g. energy, water, electricity and telecommunications) and a suitable road, rail and air infrastructure, 
private investment will be unwilling to provide fiscal support for tourist facilities. Also, a well-designed infrastructure supports and attracts tourists and brings revenue to the local actors (Brooker \& Burgess, 2008).

There is a link between the perceived purposes of investment and government policies related to tourism. For example, if tourism is part of business policy, it will be easier to attract private investors. Also, those activities and investments supporting local food and craft production can be very beneficial financially to the regional economy.

Generally the supply chain consists of the suppliers of all the products and services that go into the delivery of products/services to customers. Tourism supply chains involve many components, not just accommodation, transport and excursions, but also for example restaurants, handicrafts, waste disposal and the infrastructure that supports tourism at the destinations. Successful supply chain relationships between different enterprises and other actors consolidate the common view about goals. Also, the policy and management systems of the local authority have to support goal achievement.

According Ateljevic (2008) local authorities may play a proactive role when investing in tourist facilities, encouraging co-operation between different actors and establishing regional networks. Besides local authorities and NGOs there are many actors in the tourist sector, such as accommodation, tour and restaurant enterprises. So, as far as regional development view is concerned, it is important that networks are as multiperspective as possible. Cooperation between the local authorities and NGOs, business and other organisations assists all local actors in the region Contini, Scarpellini \& Polidori (2009). Further, Pechlaner, Raich and Fischer (Pechlaner, Raich \& Fischer, 2009) have shown the importance of cross-sector cooperation as well as the potential role of tourist organisations in an integrated location management system.

Marketing is one way to achieve strategic goals and support the regional identity. Furthermore, tourist enterprises and destinations have become aware that they need to redefine their strategies in order to respond effectively to operational environment changes such as the heterogeneity of consumers' needs, motivation and behaviours, and the changing face of global economic and social conditions.

According to Riege and Perry's model, the tourist trade has proposed three strategic approaches, which are 1) the consumer-oriented approach, 2) the competitor-oriented approach and 3) the trade-oriented approach. The first approach refers to the use of a differentiated (target marketing) or undifferentiated marketing strategy depending on market conditions. The second approach focuses on competition where the role of marketing is to develop, maintain or defend the position of a tourist organisation. The trade-oriented approach focuses on intermediaries and it might be more relevant to the travel and tourist industry. According to this approach, the distribution of travel and tourist products/services is the most important activity along the tourism chain (Tsiotsou \& Ratten, 2010; Ateljevic, 2008).

Some economists have noted that it is important to know the customer so that target markets can be clearly identified and selected and the marketing mix managed properly. This knowledge is also important for networking, because if the goals of enterprises are not clear, this might be a barrier to effective partnering and networking. They suggest that for success enterprises have to, for example, know their customers, develop detailed service standards for each market segment and know their competitors.

Nowadays the most important areas in tourism marketing are branding, consumer behaviour, e-marketing and strategic marketing. Especially have e-marketing and new technologies (e.g. mobile services such as mobile TV, mobile WEB and Web 2.0) become more significant (Tsiotsou \& Ratten, 2010). Despite these different new marketing channels, tourism service providers still need to understand the customer and increase perceived customer value by creating suitable products. The adoption of new technologies, innovative services and experiences can be designed, developed, and delivered to create higher perceived customer benefits. (Chen, Y. G., Chen, Ho, \& Lee, 2009).

In the international tourist sector cultural knowledge, cross-cultural and language skills are an important part of product and service development (Contini, Scarpellini, \& Polidori, 2009). Without these skills it is almost impossible to serve multinational customers.

\section{Types of Economic Activities in Tourism}

The main difficulty of tourist industry indicators analysis (tourism share in GDP, employment level, investment volume, tax revenue, etc.) consists in failure to refer this sector to a specific industry within the economic meaning of this word. According to a definition given in 2008 by System of National Accounts, "an industry consists of a group of establishments engaged in the same, or similar, kinds of activity" (2008 System of National Accounts, 2009, p. 92). Tourism fails to meet this definition, as far as the set of specific activities in 
tourism includes a number of industries in their traditional sense. Tourism close ties with transport, public catering, trade, etc. constituted the basis for relating a certain number of industries (types of economic activities) to the tourist industry. It's possible to use the most different level of detail of industries that depends on national economics features.

However, any detalization is based on the approach of World Tourism Organization (UNWTO), which involves defining tourism characteristic activities, corresponding to the production of tourism characteristic products. Characteristic products are products that are directly connected to tourist activity and that either cease to exist or are consumed to a significantly lesser extent in the absence of visitors. Those economic entities that release characteristic products are tourist industries.

Typical types of activities are unified at the international level. Using International Standard Industrial Classification of All Economic Activities (ISIC) they are represented in the form of 12 industries, which are used in the tables of Tourism Satellite Account (Tourism Satellite Account, 2010). This grouping is designed for common usage and can be used for information and analytic purposes. However, in certain cases (for example, for a certain country) exclusions of one or another type of activities and corresponding products (or, on the contrary, other activities' and products' inclusion) from the given list are possible. The methodology of Tourism Satellite Account allows correcting a list of tourist products and types of activities in accordance with established criteria and features of national economy.

In order to reflect the maximum credible level of tourism impact on the country's economy ( $100 \%$ confidence is essentially impossible in this case) it's necessary to point out those groups of economic activity that have a direct relationship to tourism. Then it's necessary to introduce a diminishing (adjusting) coefficient $\left(\mathrm{C}_{\mathrm{d}}\right)$ for each group, which characterizes tourism share in enterprises' activities of the given group by means of expert evaluation.

The use of coefficient will allow avoiding over-estimation of tourism role in economic activity, and also receiving estimates of various macroeconomic parameters. For example, it's possible to receive estimation of tax payments rates to budget of tourist activity carrying out. Thus, according to public tax accounts data on the consolidated group "air transport activity" the consolidated budget of Russia received more than $500 \mathrm{mln}$. dollars of taxes and charges in 2013. This amount involves all tax payments from enterprises, working on the passenger and freight market (besides, according to the Russian classifier this group also involves space transport activity). Obviously, some part of tax payments falls at tourism. It should be considered by two groups of Russian National Classifier of Economic Activities (OKVED) only, besides, taxes of one of these groups (62.20.1 "non-scheduled air-passenger transport activity") are very closely related to tourism as it is referred to charter flights. For this group a coefficient should be one. However, taxes of airlines, engaged in freight service, have nothing to do with tourist revenue and for this reason should not be taken into account when estimating tax burden rate of this sphere. The use of diminishing coefficients allowed us to make a conclusion that tourist tax payments of air transport activity in 2014 was not more than $35-45 \mathrm{mln}$. dollars countrywide.

\section{Tourism Industry in Russia: Trends and Successes}

In the period after the beginning of market reforms the Russian tourism passed a number of stages marked by various trends. We distinguish three of such stages (Ovcharov, 2008).

The first stage (1992-2002) was characterized by politico-social and macroeconomic instability attributable to the beginning of market reforms. The main feature of the period is the absence of distinct national policy in the field of internal and inbound tourism, tourist economic sector material and technical basis obsoletion and investment activities stagnation.

The absence of attention to the problems of tourist industry for the first years of reforms appeared to be the reason of consumers' mass refocusing from internal to foreign tourist market. Outbound tourism had been gradually becoming the most popular sphere of recreation for the Russian citizens. Thus, in 1995 volumes of outbound tourism was 2607 thou. travels, in 2002-5044 thou. travels (Tourism and Tourist Resources in Russia, 2004). Tourists programs with incomplete service package: "tourist trader" business or shopping tours, which provided accommodation and transport services only - were much sought after. The tourist industry of Russia experienced reduction of collective accommodation establishments' network and the amount of tourists they served.

The second stage (2002-2008) can be defined as "tourist boom" on the market of tourist services, which was related to overcoming crisis phenomena in the Russian economy and rising of living standards. The share of tourist services, elastic by incomes, had been rising under the conditions of slight growth of real size of money income of population. External trade turnover of tourist services and tourists sector investments began to 
increase, inflation began to slow down. However, "tourist boom" was generally focused on outbound tourism.

The third stage (2009-date) is a period of repletion of consumer demand on the market of tourist services, entering the world economic crisis and relatively fast recovery of its consequences.

The dynamics of main economic indicators of tourist industry in Russia for the last years is shown in Table 1. The presence of positive trends is obvious. Thus, the amount of both independent hotels and world hotel chains (such brands as Hilton, Kempinski, Radisson SAS, Novotel, Park Inn and others are actively promoted into the Russian market) in Russia has increased in recent years, their hotel room capacity and load level have also increased. The same is true for public catering and entertainment industries. Index of employment in tourist sector, international tourism receipts and tourist arrivals have reached pre-crisis level. Currently, many indicators of tourism demonstrate positive changes.

Table 1. Dynamics of indicators of tourism in Russia

\begin{tabular}{|c|c|c|c|c|c|c|c|c|}
\hline Indicators & 2006 & 2007 & 2008 & 2009 & 2010 & 2011 & 2012 & 2013 \\
\hline \multicolumn{9}{|l|}{ 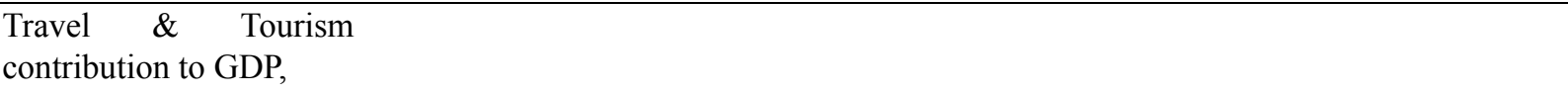 } \\
\hline direct & 1.4 & 1.4 & 1.4 & 1.5 & 1.4 & 1.3 & 1.4 & 1.4 \\
\hline total & 5.8 & 5.9 & 5.8 & 6.4 & 5.9 & 5.7 & 5.8 & 5.8 \\
\hline $\begin{array}{lr}\text { Travel \& } & \text { Tourism } \\
\text { contribution } & \text { to } \\
\text { employment. thou. jobs: }\end{array}$ & & & & & & & & \\
\hline direct & 944.6 & 962.2 & 959.5 & 1018.4 & 955.0 & 923.9 & 966.3 & 966.8 \\
\hline total & 3762.0 & 3898.6 & 3887.5 & 4139.5 & 3875.7 & 3787.6 & 3931.5 & 3934.9 \\
\hline $\begin{array}{l}\text { Number of travels of } \\
\text { foreign citizens into } \\
\text { Russia (far abroad } \\
\text { countries; thou. visits) }\end{array}$ & 8817 & 8347 & 8551 & 8361 & 8266 & 9194 & 10175 & 10869 \\
\hline \multicolumn{9}{|l|}{$\begin{array}{l}\text { of which by purpose of } \\
\text { travel: }\end{array}$} \\
\hline business & 2417 & 2293 & 2945 & 2755 & 3035 & 3753 & 4058 & 3516 \\
\hline tourism & 2275 & 2123 & 2168 & 2000 & 2025 & 2228 & 2430 & 2506 \\
\hline private & 3133 & 2853 & 2389 & 2663 & 2174 & 2121 & 2483 & 3582 \\
\hline $\begin{array}{l}\text { Number of travels of } \\
\text { Russian citizens from } \\
\text { Russia to abroad (far } \\
\text { abroad countries; thou. } \\
\text { visits) }\end{array}$ & 15666 & 18692 & 20464 & 21638 & 25487 & 29271 & 33142 & 38521 \\
\hline \multicolumn{9}{|l|}{$\begin{array}{l}\text { of which by purpose of } \\
\text { travel: }\end{array}$} \\
\hline business & 1898 & 1712 & 1614 & 1043 & 1133 & 1203 & 975 & 801 \\
\hline tourism & 7132 & 9041 & 10822 & 9192 & 12231 & 14052 & 14816 & 17682 \\
\hline private & 5246 & 6071 & 6072 & 9879 & 10188 & 11962 & 15141 & 17746 \\
\hline $\begin{array}{l}\text { Market services rendered } \\
\text { to population - total, \% } \\
\text { of which: }\end{array}$ & 100 & 100 & 100 & 100 & 100 & 100 & 100 & 100 \\
\hline tourist services & 1.6 & 1.6 & 1.8 & 1.7 & 2.0 & 2.0 & 2.0 & 2.1 \\
\hline $\begin{array}{l}\text { spa and resort treatment } \\
\text { services }\end{array}$ & 1.5 & 1.4 & 1.4 & 1.4 & 1.2 & 1.2 & 1.3 & 1.0 \\
\hline
\end{tabular}




\begin{tabular}{|c|c|c|c|c|c|c|c|c|}
\hline $\begin{array}{l}\text { hotels and similar } \\
\text { establishments services }\end{array}$ & 2.7 & 2.7 & 2.6 & 2.4 & 2.3 & 2.3 & 2.3 & 2.3 \\
\hline \multicolumn{9}{|l|}{$\begin{array}{l}\text { Consumer prices indices } \\
\text { for tourism services } \\
\text { rendered population (at } \\
\text { the end of period; } \\
\text { percentage as compared } \\
\text { to december of the } \\
\text { previous year): }\end{array}$} \\
\hline $\begin{array}{l}\text { international tourism } \\
\text { services }\end{array}$ & 104.3 & 106.2 & 122.9 & 107.8 & 100.2 & 105.4 & 103.4 & 109.1 \\
\hline $\begin{array}{l}\text { spa and resort treatment } \\
\text { services }\end{array}$ & 115.2 & 115.6 & 121.2 & 109.5 & 105.4 & 109.0 & 105.9 & 105.7 \\
\hline excursion services & 107.1 & 115.6 & 122.3 & 110.1 & 104.8 & 106.5 & 108.8 & 115.0 \\
\hline \multicolumn{9}{|l|}{$\begin{array}{l}\text { Main indicators } \\
\text { collective } \\
\text { accommodation } \\
\text { establishments: }\end{array}$} \\
\hline $\begin{array}{l}\text { number of hotels and } \\
\text { similar facilities for } \\
\text { accommodation }\end{array}$ & 5375 & 5917 & 6774 & 7410 & 7866 & 8406 & 9316 & 9855 \\
\hline $\begin{array}{l}\text { number of sanatoria and } \\
\text { resort establishments and } \\
\text { recreation organizations }\end{array}$ & 4490 & 4519 & 4484 & 4034 & 3886 & 3862 & 3592 & 3498 \\
\hline $\begin{array}{l}\text { number of patients } \\
\text { served, thou. persons }\end{array}$ & 10493 & 10763 & 11031 & 9780 & 9709 & 9514 & 9063 & 8951 \\
\hline $\begin{array}{l}\text { number of children } \\
\text { sanitation } \\
\text { thousand }\end{array}$ & 52.0 & 51.7 & 52.2 & 51.0 & 50.2 & 49.2 & 47.9 & 46,7 \\
\hline
\end{tabular}

Source: data was summarized by the authors based on various forms of official Russian statistics (Russia in Figures, 2013), UNWTO (UNWTO Tourism Highlights Edition, 2013), and World Travel \& Tourism Council (WTTC Economic Data Search Tool, 2013).

We distinguish two main reasons for success of the modern Russian tourism. The first one is related to the increasingly prominent role of the government in tourist market regulation. A system of measures, focused on tourist economic sector support and regulation, operates at the federal and regional level. The regulation of tourist market is carried out in all domains including regulatory, organizational, economic, scientific \& educational, and social. Besides, state financing of tourism and recreation holds a specific place. Thus, at the end of 2012 a state-run program "Razvitie zdravoohraneniya" ("Health development") was adopted, which involves sponsoring governmental health resort establishments of the country (pensionates, sanatoria, etc.). Money will be spent on both current problems solution (rehabilitation, health resort treatment, children's recreation, etc.) and capital investments to infrastructure. The amount of finance of federal budget for these goals over the term of the program (to 2020) should be more than 2 bln. dollars. Another project allocates approximately $10 \mathrm{bln}$. dollars of investments. It is a government program "Razvitie vnutrennego i v'ezdnogo turizma v Rossiyskoy Federatsii" ("Development of the inbound and outbound tourism in the Russian Federation") (2011-2018). Its main idea is to stimulate tourism in Russia not throughout the country, but only in the most promising regions in the context of inbound and outbound tourism development. For this purpose it's suggested to use a cluster approach (to create two types of clusters - tourist recreational and autotourist), and carry out financing by means of state funds and private investments. Finally, the third project running on the same principles (cluster approach and public-private partnership) has been active in Russian since 2007 - special economic zones of Tourism \& Recreation. In the context of this project construction of tourist objects (including associated infrastructure), located in different regions of the country, is carried out. For example, it's supposed to spend more than $200 \mathrm{mln}$. dollars of 
government investments for one special area within the Altai Territory alone. Tax incentives, rent privileges, free custom zone regime, partial subsidizing of interest rates of bank loans are established for the residents of specific recreation areas. The similar measures were assumed in 80s of the previous century in Turkey, namely, the law "Concerning the investments in the field of Tourism" (1982) provided various preferences, particularly, concessional lending of investment projects and VAT remission with the purchase of locally manufactured equipment for tourist objects facilities. Implementation of these measures allowed Turkey to turn from the obvious outsider into the one of the world leaders in the volume of inbound tourism and tourist services export for 10-15 years.

The second reason for the Russian tourism success is attributable to the new model of consumer behaviour that is forming in the country. While twenty years ago the base consumption model of households was the strategy of survival, currently many economists suggest new consumer's standard forming, in the context of which, possibilities of households to invest resources in their quality of life improvement appear. Combating poverty is no longer the main target of social policy - analysis of income and revenue structure, expenditures and consumption of households shows that survival model has ceased to be a mass model despite persisting wealth disparity (Ovcharova \& Popova, 2013). It was replaced by the model of stable development, the feature of which is high share of services expenses in population's general expenses. While in 1997 this share was $14.9 \%$, it has reached a quarter of consumption expenditures' overall volume in recent years, and in comparison with 1992 (the year of market reforms' beginning in Russia) it has increased thrice. Furthermore, more than $5 \%$ of all paid market services falls at three groups of tourist and related services (see Table 1). If we take into account that a certain part of transport and consumer services, services in the field of sport and culture is indirectly connected to tourism, then the given share reaches $7-10 \%$. In this respect, the tourism may become one of the main drivers of new model of consumption - tourist expenditures along with education and health expenditures form absolutely different quality of human capital assets.

Further, we turn our attention to the structure and methods of statistical analysis of tourist expenditures.

\section{Competitive Ability of Russia on the World Tourist Market: Risk Factors}

Let's examine general processes of international tourism in the context of participation of Russia in them. The active development of international tourism has begun in post-war period, what can be explained with the growth of population number in the industrial countries, increase of paid holidays and household incomes. The single facts of tourism development recession, caused by political and economic problems, have not canceled the steady trend of growth of tourist streams and associated incomes and expenditures. Within the period of 1950-2005 the average annual growth of tourist arrivals had made up $6.5 \%$. The reducing of arrivals over that period was observed only three times: in 1982 - in consequence of global economic slowdown; and in 2001 and 2003 - as a result of international terrorism burst. The greatest contribution into the dynamics was made by Asia and the Pacific region: for 55 years the tourist arrivals here have been increasing at average by $12.5 \%$ per year. The following are: Middle East (10.1\%), Africa (8.1\%), Europe (6.1\%) and America (5.4\%). The priority of Asia and the Pacific region is due to its high tourist attractiveness in 1960-80, i.e. in the period of fast economic recovery of Japan and some new industrial countries (Malaysia, Thailand, Taiwan, etc.). In subsequent years this region had been gradually giving up positions to the countries of Middle East.

However, regarding the absolute measure of tourist arrivals and receipts, the permanent leader is Europe. It possesses developed infrastructure and the biggest number of tourist areas. Thus, according to the results of 2012, the number of tourists who had visited Europe is equal to $534.2 \mathrm{mln}$. people, or $51.6 \%$ of total number, while receipts had compiled $457.8 \mathrm{mln}$. dollars, or $42.6 \%$.

The world crisis of 2008-2009 has demonstrated the fourth and the last by this moment reduction of tourist receipts. In 2009 they have reduced by 3.7\% in comparison with 2008. In consequence of global economic crisis aggravated by high (however, not realized) probability of A(H1N1) flue pandemic, 2009 has become one of the most difficult year in the context of tourism.

More detailed picture illustrating trends of the last years is represented in Table 2. Despite the menace of socioeconomic and political risks, regions and subregions demonstrated sustainable growth of tourist sector up to 2009, with the following recovery in 2010. In 2011 the volume of international tourist incomes has for the first time made up more than 1 billion dollars, and in 2012 there were more than 1 billion arrivals. In the rating of world export the tourism takes the 4th place after Fuel \& Energy Complex, chemical and automobile industries. 
Table 2. International tourist incomes and arrivals

\begin{tabular}{|c|c|c|c|c|c|c|c|c|c|c|}
\hline & 2004 & 2005 & 2006 & 2007 & 2008 & 2009 & 2010 & 2011 & 2012 & 2013 \\
\hline \multicolumn{11}{|c|}{ International tourist arrivals. mln. people } \\
\hline $\begin{array}{l}\text { World } \\
\text { including: }\end{array}$ & 764.4 & 806.9 & 845.7 & 901.1 & 916.7 & 883.2 & 949.1 & 994.9 & 1035.3 & 1086.8 \\
\hline Europe & 424.4 & 448.9 & 463.9 & 485.4 & 485.2 & 461.7 & 485.5 & 516.4 & 534.2 & 563.4 \\
\hline Americas & 125.7 & 133.3 & 135.8 & 143.9 & 147.8 & 141.7 & 150.4 & 156.0 & 163.1 & 167.9 \\
\hline $\begin{array}{l}\text { Asia and } \\
\text { the Pacific }\end{array}$ & 144.2 & 153.6 & 166.0 & 182.0 & 184.1 & 181.1 & 205.1 & 218.2 & 233.6 & 248.1 \\
\hline $\begin{array}{l}\text { Middle } \\
\text { East }\end{array}$ & 36.3 & 36.3 & 40.9 & 46.7 & 55.2 & 52.8 & 58.2 & 54.9 & 52.0 & 51.6 \\
\hline Africa & 33.8 & 34.8 & 39.1 & 43.1 & 44.4 & 45.9 & 49.9 & 49.4 & 52.4 & 55.8 \\
\hline \multicolumn{11}{|c|}{ International tourism receipts. bln. Dollars } \\
\hline $\begin{array}{l}\text { World } \\
\text { including: }\end{array}$ & 633.0 & 679.7 & 744.7 & 857.7 & 939.8 & 853.2 & 930.2 & 1042.3 & 1074.9 & 1158.9 \\
\hline Europe & 328.5 & 350.3 & 378.3 & 435.4 & 471.8 & 412.3 & 412.0 & 466.7 & 457.8 & 489.3 \\
\hline Americas & 132.0 & 145.3 & 154.5 & 171.4 & 189.1 & 166.1 & 180.8 & 197.9 & 212.6 & 229.2 \\
\hline $\begin{array}{l}\text { Asia and } \\
\text { the Pacific }\end{array}$ & 127.8 & 135.0 & 157.1 & 186.3 & 208.6 & 204.2 & 254.7 & 298.6 & 323.9 & 358.9 \\
\hline $\begin{array}{l}\text { Middle } \\
\text { East }\end{array}$ & 25.5 & 27.3 & 29.9 & 35.0 & 40.0 & 42.2 & 52.2 & 46.4 & 47.0 & 47.3 \\
\hline Africa & 19.2 & 21.8 & 24.9 & 29.6 & 30.3 & 28.4 & 30.5 & 32.7 & 33.6 & 34.2 \\
\hline
\end{tabular}

The main factors determining modern economic dynamics are change of level of world incomes, investments into infrastructure, marketing, advertising and also liberalization of air transport (in particular, spreading of low-budget airlines), development of interregional cooperation, and government and private partnerships.

For the long time Europe and America have been leading the world ratings in absolute indicators. They have still possessed quite high concentration of international tour itineraries, significant diversification of tourist product and the most developed infrastructure. However, in these latter days rates of growth of these leaders have come short of rates of growth of other regions. In 2002 Asia and the Pacific region had beaten America in international tourist incomes and become the second most-visited area after Europe.

In pre-crisis and post-crisis periods Asia and the Pacific region has occurred to be the leader regarding the rates of growth of this indicator. Its international tourism incomes had been also rapidly increasing. In 2006 its incomes had matched with American incomes and then have been increasing at quick rates. Notably that world crisis had reduced their level in quite insignificant way: in 2009 in comparison with 2009 tourist receipts in Asia and the Pacific region had reduced only 4.4 bln. dollars, while in Europe the reduction had made up 59.5 bln. dollars, and in America -23.0 bln. dollars. A prominent part here was played by incomes from individual tours (Thailand, Indonesia), business tourism (Japan) and shopping tours (China, Singapore).

America, which for a long time took up predominant positions, over time loses its advantages. Within the period of 2005-2008 it demonstrated the worst results in the dynamics of tourist arrivals and incomes. Surmounting the world crisis of 2008 was also quite hard. Slackening of American continent positions can be explained with drop in demand for long-distance travels and development of intraregional tourism. Other reasons involve consequences of severe natural disasters and international terrorism risks.

One of the current important trends is a strong growth of African region. In 80-90s of the previous century the limiting factor of inbound tourism development here was the high level of prices and political instability. However, the shift towards available mass recreation, development and diversification of tourist services and infrastructure formation had turned out to be quite efficient. In 2008 foreign exchange earnings of African region had reached almost 30 bln. dollars, what is 7 times more than in 1990. In general, tourist industry of Africa 
promotes economic upturn and job creation and plays significant role in combating poverty.

Thus, we can conclude that development of international tourism is characterized with regional inequality. There is a big amount of factors which have an impact on it, for example, the farness of tourist zones from usual living areas, currency fluctuations, variety of culture-historical and natural resources, tourist infrastructure sophistication, image of a country on the world stage, etc. What is for Russia, here we can say one of the main factors that of paramount importance is the degree of its national economy entry into the system of international trading of goods and services. For a long time Russia was isolated from the rest of the world in political and economic respect. This could not have been insensibly for the character of tourism that in general was aimed at interior customers and had been exported tourist services in a quite limited volume. The situation started changing only with the beginning of market reforms. Feverish demand of Russian citizens for foreign travels resulted from the fall of iron curtain and the interest of foreign citizens towards previously unknown tourism objects have lead to the gradual consolidation of Russian tourism positions on the world market. According to the data of UNWTO, in 2012 Russia entered the top ten of worldwide leaders in two indexes: international tourist arrivals (9th position) and international tourism expenditures (5th position) (UNWTO Tourism Highlights Edition, 2013).

Along with this, the analysis of tourist streams for twenty-year period gives us an opportunity to reveal some interesting trends. In 90s years of the previous century there was rapid growth of foreign tourists' entry into Russia. This growth had attained a maximum in the beginning of 2000 s and stabilized in subsequent years up to the level of a bit more than $2 \mathrm{mln}$. arrivals a year. In separate periods (for example, in 2005, 2007 or 2009) there was slight downturn, while in other (for example, in 2006, 2010 or 2012) — slight growth. However, we have absolutely another situation with outbound streams: except for 2001 and two crises (the Russian domestic crisis of 1998 and the world crisis of 2008-2009) there was no year when the volumes of outbound tourism would reduce. In 2012 in comparison with 1993 the number of Russian citizens' tourist travels has increased almost 10 times. Moreover, there is growth of both - the number of Russian citizens, who leave for foreign country for the first time, and those ones, who go abroad two, three and even more times a season.

Increase of demand for rest abroad was confirmed by market monitoring held among residents of Moscow and the Moscow Region in 2005. From among 200 thousand people only $15.2 \%$ of citizens would like to have a rest in midland of Russia and $6.3 \%$ - in southern areas. The majority of Moscovites wishes to have a rest in other countries. The leaders here are: Turkey (13.6\%), Egypt (9.1\%) and the Ukraine (4.6\%). Another one trend is the demand for comfortable rest in European resort zones.

The main problem of current Russian tourism is that it's aimed at outbound tourism, not at inbound or internal tourism. In Figure 1, there are results of our estimates of Russian tourism specific indicators in the world tourist industry. It is obvious that the main economic indicator of "international tourism receipts" is being extremely insignificant for the country possessing so large territory and various tourist resources. 


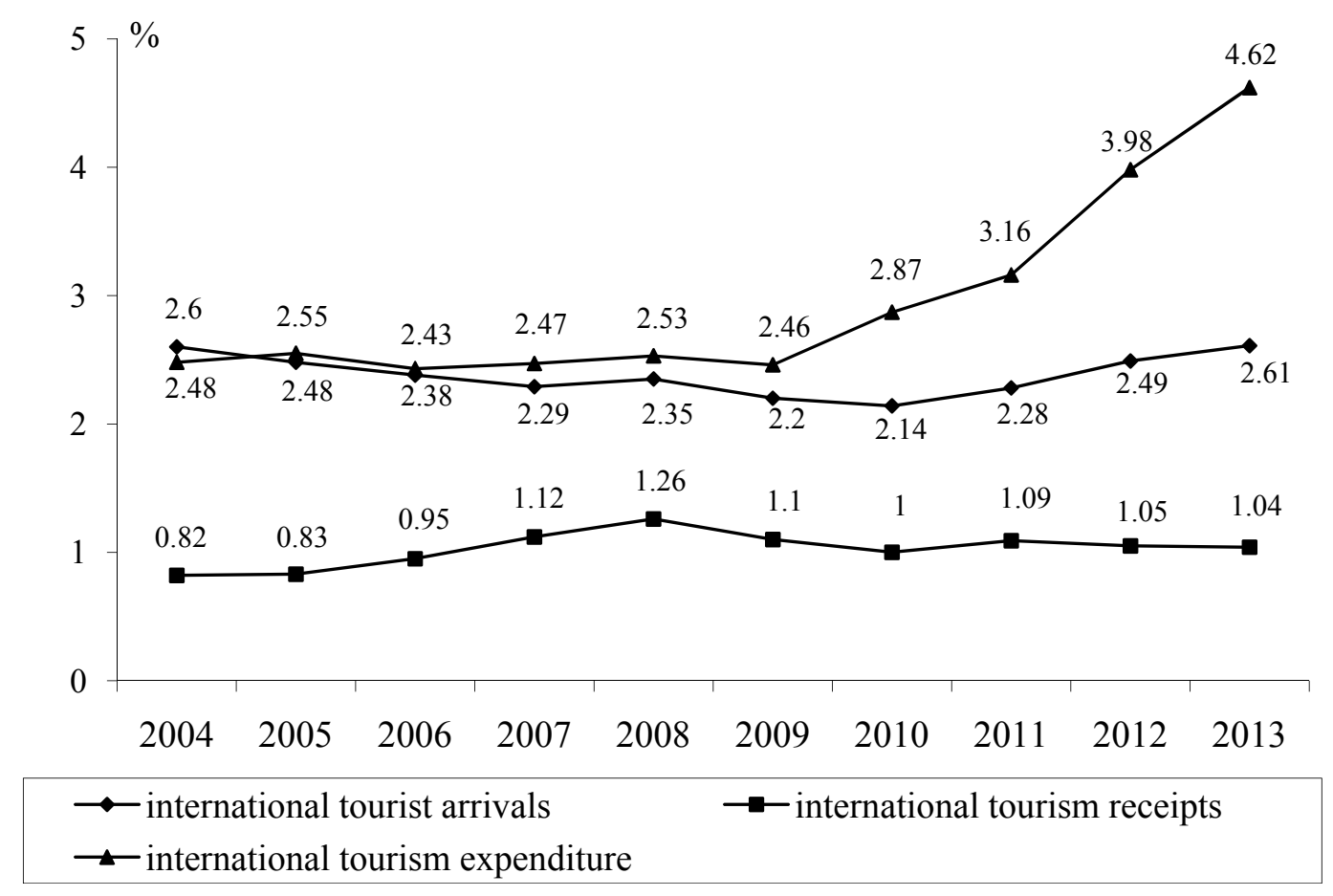

Figure 1. The share of Russia in international tourist arrivals, tourism receipts and expenditure

In Russia, besides increasing gap between export and import of tourist services, risk factors also cover disproportionality of regional infrastructure, high level of prices for internal tourist services and absence of efficient marketing concerning different tourist programs. We should also take into account political and corruption risks and menace of terrorism which remains primarily on the territory of the Northern Caucasia. These are indirectly confirmed by the data of World Economic Forum: according to the Travel \& Tourism Competitiveness Index 2013, Russia takes the 63rd place of the rating including 140 countries (its summary index=4.16). This is 4 positions lower than in case of the previous rating. And if due to its natural and cultural and historical potential Russia gets rather high subrating, its safety level (the 113th place) gives cause for quite serious concerns of international experts and peculiarly of international tourists. Thus, according to the official Russian statistics, in 2012 within the collective accommodation establishments of two Caucasian republics (Chechnya and Ingushetia) no tourist had been staying, while Moscow and St. Petersburg were visited by more than $1 \mathrm{mln}$. foreign tourists.

In such a way, definite progress equates with problems and risks which indicate the non-use of Russian internal tourist potential. Many countries (the Netherlands, Sweden, Belgium, etc.) possessing the same or even lesser tourist resources (Note 1), nevertheless, take higher positions in the world rating. The indicators of world's leading tourist destinations (France, USA, Spain, etc.) are being absolutely incommensurable with Russia. It is obvious that Russia today can hardly compete with the favorites of world tourist industry. Its main competitive advantage - natural and sociocultural contrasts, which can help in developing any kinds of tourism at any time of year-Russia uses in quite ineffective way. To overcome this inefficiency and mitigate risks Russia needs to activate its investing activities (particularly, in the sphere of attraction of foreign investments), develop and diversify tourist product, form modern hotel and transport infrastructure not only in Moscow and St. Petersburg, but in other regions too. Significant attention should be paid to the formation of country's positive image on the world arena. All these factors will provide the possibility of creation of up-to-date hi-tech economic sector, which will be able to compete with world's leading tourist centers.

\section{Conclusions}

This paper shows that the use of statistic analysis methods helps to set limits for tourist economic sector. On the basis of ISIC we have detailed definite kinds of economic activity concerning international tourism as well as the tourist sector of particular country (Russia). We have also offered the use of adjusting factors considering the part of tourism in the activity of enterprises of various branches. 
Using actual statistical data we have revealed the trend of developing tourism in Russia and the whole world. We have also shown the inequality of international tourist arrivals and expenditures. The main reasons for Russian tourism success were identified. They are: wide public support and formation of new model of households' management intending high customer share in the services sector. Along with this, we have concluded the tourist industry of Russia is aimed at outbound tourism. High level of political and corruption risks, menace of terrorism, disproportionality of regional tourist infrastructure indicate low competitiveness of Russian tourism on the world market. This is confirmed with statistical data-the gap between international tourist expenditure and international tourism receipts increases from year to year, that leads to significant negative balance of foreign trade in respect to tourist services.

\section{Acknowledgment}

This research was partially supported by the Ministry of education and science of Russia as a part of the state assignment, Project Number 2648.

\section{References}

2008 System of National Accounts. (2009). Organisation for Economic Co-operation and Development. New York: European Commission, International Monetary Fund.

Ateljevic, J. (2008). Tourism entrepreneurship and regional development: Example from New Zealand. International Journal of Entrepreneurial Behaviour \& Research, 15(3), 282-308. http://dx.doi.org/10.1108/13552550910957355

Brooker, E., \& Burgess, J. (2008). Marketing destination Niagara effectively through the tourism life cycle. International Journal of Contemporary Hospitality Management, 20(3), 278-292. http://dx.doi.org/10.1108/09596110810866091

Chen, Y. G., Chen, Z-H., Ho, J. C., \& Lee, C-H. (2009). In-depth tourism's influences on service Innovation. International Journal of Culture, Tourism and Hospitality Research, 3(4), 326-336. http://dx.doi.org/10.1108/17506180910994541

Contini, C., Scarpellini, P., \& Polidori, R. (2009). Agri-tourism and rural development: The Low-Valdelsa case. Tourism Review, 64(4), 27-36. http://dx.doi.org/10.1108/16605370911004557

Cooper, C., Fletcher, J., Gilbert, D., Shepherd, R., \& Wanhill, S. (1999). Tourism: Principles and practice (2nd ed.). New York, USA: Addison Wesley Longman Publishing.

Dereli, C. (2003). Strategy and strategic decision-making in the smaller local authority. International Journal of Public Sector Management, 16(4), 250-260. http://dx.doi.org/10.1108/09513550310480024

Ovcharov, A. (2008). The Russian tourist industry: Trends and risks. Social Sciences, 39(3), 4-15.

Ovcharova, L. N., \& Popova, D. O. (2013). Receipts and expenditures of Russian households: What has been changed in mass consumption standard. Society and economics, 3, 3-34.

Pechlaner, H., Raich, F., \& Fischer, E. (2009). The role of tourism organizations in location management: The case of beer tourism in Bavaria. Tourism Review, 64(2), 28-40. http://dx.doi.org/10.1108/16605370910963509

Russia in Figures. (2013). Statistical Handbook. Retrieved from http://www.gks.ru/bgd/regl/b13_12/IssWWW.exe/Stg/d02/26-01.html

Sharma, B., \& Dyer, P. (2009). Residents' involvement in tourism and their perceptions of tourism impacts. Benchmarking: An International Journal, 6(3), 351-371.

The Travel \& Tourism Competitiveness Report. (2013). Retrieved from http://www3.weforum.org/docs/WEF_TT_Competitiveness_Report_2013.pdf

Tourism and Tourist Resources in Russia. (2004). Statistical Handbook. Retrieved from http://www.gks.ru/bgd/regl/b04_42/IssWWW.exe/Stg/d010/i010040r.html

Tourism Satellite Account: Recommended Methodological Framework. (2010). World Tourism Organization, Commission of the European Communities, Organisation for Economic Co-operation and Development. New York: United Nations.

Tsiotsou, R., \& Ratten, V. (2010). Future research directions in tourism marketing. Marketing Intelligence \& Planning, 28(4), 533-544. http://dx.doi.org/10.1108/02634501011053702
UNWTO
Tourism
Highlights
Edition.
(2013).
Retrieved
from 
http://dtxtq4w60xqpw.cloudfront.net/sites/all/files/pdf/unwto_highlights13_en_hr.pdf
WTTC
Economic
Data
Search
Tool.
(2013).
Retrieved
from

http://www.wttc.org/research/economic-data-search-tool/

\section{Note}

Note 1. In the list of world heritage of UNESCO (for 2012) there were 25 Russian natural and culture-historical objects, what makes up 2,5\% of total number. Another 26 objects rank among the candidates for listing.

\section{Copyrights}

Copyright for this article is retained by the author(s), with first publication rights granted to the journal.

This is an open-access article distributed under the terms and conditions of the Creative Commons Attribution license (http://creativecommons.org/licenses/by/3.0/). 